\title{
Caracterización y propuestas de mejora de los sistemas de producción caprina de la costa central de Perú
}

\section{Characterization and proposals for the improvement of goat production systems of the Peruvian coast}

\author{
J osé A. Sarriaa, Francisco A. Ruizb, Yolanda Menac, J osé M. Casteld
}

\begin{abstract}
RESUMEN
Perú tiene un importante sector caprino con rebaños de aptitud cárnica o mixta. Sin embargo, en los valles de la costa central hay una mayor tendencia a la orientación lechera, alimentando a los animales en base a rastrojos agrícolas. El objetivo de este estudio fue caracterizar las explotaciones de esta zona, para lo cual se entrevistaron 60 ganaderos y se analizaron 39 variables. Se realizó un análisis multivariante seguido de un ANOVA entre los cuatro grupos resultantes del mismo; obteniéndose dos dimensiones que explican el $69.9 \%$ de la varianza. Ocho variables mostraron diferencias significativas: (i) educación del ganadero, los niveles primario y secundario predominaron respectivamente en los Grupos 2 y 3, P<0.05; (ii) superficie de explotación, menos de 0.50 ha a excepción del Grupo 1, $\mathbf{P}<0.05$; (iii) modo de propiedad de la tierra, la propiedad privada fue menor en el Grupo 1, P<0.01; (iv) importancia de las cabras, la producción caprina es la principal actividad del ganadero en los Grupos 3 y 4, P<0.001; (v) número de caprinos, 97 y 80 respectivamente en los Grupos 1 y 4 y menos en el resto; $P<0.001$ ); (vii) número de bovinos, 18 y 16 respectivamente en los Grupos 1 y 2 , y menos en el resto, $P<0.001 ; y$ (viii) suministro de alimentos en la granja, no existiendo éste en los Grupos 1 y 4, $\mathrm{P}<\mathbf{0 . 0 1}$. Para tener continuidad y mejora, estos sistemas de producción caprina deberían reorganizarse de forma global, incrementar el tamaño de las explotaciones y tratar de comercializar productos diferenciados.
\end{abstract}

PALABRAS CLAVE: Pastoreo de rastrojos, Análisis de escalonamiento óptimo, Análisis cluster.

\begin{abstract}
Peru has an important goat sector, based mainly on mixed or meat purpose herds. Nevertheless, in Peruvian central coast valleys, goats are more oriented to milk purpose, being the animal feeding based on graze crop stubbles. The objective of this study was to characterize farms of this area. Sixty (60) farmers were interviewed and 39 variables were used in the study. A multivariate analysis followed by an ANOVA among the four obtained clusters was conducted. Two dimensions were obtained explaining $69.9 \%$ of variance. Eight variables showed statistical differences: (i) farmer's education level, primary and secondary level predominate respectively in Clusters 3 and $2, P<0.05$ ); (ii) farm surface area, less than 0.50 ha except in Cluster 1, P<0.05; (iii) type of land ownership, private was lesser in Cluster 1, P<0.01; (iv) importance of goats, goat production was the main farmer activity in Clusters 3 and 4 , P<0.001; (v) number of goats, 97 y 80 respectively in Clusters 1 and 4 and less in the other clusters; P<0.001); (vii) number of bovines, 18 and 16 respectively in Clusters 1 and 2 and less in the other clusters, $P<0.001 ;$ and (viii) feeding supply in the trough, farmers did not supplied feed in Clusters 1 and $4, P<0.01$. These production systems should be improved globally for their continuity. Likewise, the holding size increasing would be appropriate and the trading of singular products should be driving.
\end{abstract}

KEY WORDS: Stubble grazing, Optimal scaling analysis, Cluster analysis.

Recibido el 7 de febrero de 2014. Aceptado el 24 de marzo de 2014.

a Departamento de Producción Animal, Facultad de Zootecnia, Universidad Nacional Agraria La Molina, Avenida Universidad s/n, La Molina, Lima, Perú.

b Instituto de Investigación y Formación Agraria y Pesquera de la J unta de Andalucía (IFAPA), Granada, España. franciscoa.ruiz@juntadeandalucia.es. Correspondencia al segundo autor.

c Escuela Técnica Superior de Ingenieros Agrónomos (ETSIA), Universidad de Sevilla, Sevilla, España.

d Profesor jubilado. Sevilla, España.

Financiación: Plan Propio de la Universidad de Sevilla para proyectos de desarrollo. 


\section{INTRODUCCIÓN}

La información sobre los sistemas de producción caprina de las áreas tropicales, subtropicales y áridas de América es en general pobre o está poco actualizada. Se han llevado a cabo pocos estudios de caracterización global de sistemas de producción animal en Perú con rebaños de cabras, principalmente de aptitud cárnica(1). Estudios que tratan de aspectos parciales de los sistemas de producción animal son más frecuentes, por ejemplo los análisis descriptivos, principalmente con cabras de aptitud cárnica en Argentina(2) y con rebaños caprinos de aptitud mixta de la costa peruana(3). Otros autores estudiaron aspectos socioeconómicos de los sistemas caprinos, con rebaños de diferentes aptitudes en Venezuela(4) y con caprinos de aptitud cárnica de Argentina(5). También hay trabajos que se refieren a la producción y a los canales comerciales del sector caprino a partir de rebaños de aptitud mixta en Venezuela(6). Y finalmente, se estudiaron algunos aspectos de los sistemas caprinos que podían mejorarse (genética, reproducción y alimentación) en rebaños extensivos de aptitud cárnica de áreas áridas del norte de México(7).

La producción caprina en Perú se sitúa en tres áreas (Figura 1): la costa norte (CN), el oeste de los Andes (OA) y los valles de la costa central (VCC). En la CN, las cabras se explotan en sistemas extensivos mediante el pastoreo en bosques secos; la principal producción en este caso son los cabritos para carne(1). En el OA, las cabras pastan en los cañones interandinos; mientras que en los VCC, las cabras principalmente pastorean los rastrojos de los cultivos, aunque en algunas explotaciones $y$ en algunas estaciones del año, los rebaños practican la trastermitancia (aprovechando pastos naturales)(3). A lo largo del año, las cabras de los VCC consumen rastrojos, principalmente de maíz y hortalizas en verano; de algodón, mandioca, espárragos y hortalizas en invierno. El otoño y la primavera son períodos de transición. En algunos casos los rastrojos son del propio ganadero, que es agricultor

\section{INTRODUCTION}

The information on goat production systems in tropical, subtropical and arid areas in America is generally poor or outdated. Some studies have been conducted on the global characterization of animal production systems in flocks of goats in Peru, especially for meat production(1). Studies addressing partial aspects of animal production systems are more frequent, for example descriptive studies of goat production systems in mainly meat purpose goat flocks in Argentina(2) and in mixed purpose goat flocks on the Peruvian coast(3). Other authors studied the socio-economic aspects of goat systems, in herds of different aptitudes in Venezuela(4) and in meat purpose goat flocks of Argentina(5). Some papers also refer to the production or commercial channels in the goat sector from mixed purpose flocks of Venezuela(6). Finally, some aspects of goat production systems which could be improved (genetic aspects, reproduction and feeding) were studied in extensive meat purpose herds in arid areas of northern Mexico(7).

The Peruvian goat production is situated in three areas (Figure 1): the Northern coast (NC), Western Andes (WA) and Central coast valleys (CCV). In the NC zone, goats are managed in an extensive system by grazing in dry forests and kids are the main production(1). In the WA, goats graze in the Andean canyons, while in the CCV, goats basically graze crop stubble, although on some farms and in some seasons, a minor form of transhumance (grazing rangelands) is practiced(3). Throughout the year, farmers of the CCV use stubble, mainly of maize and vegetable in summer, and of cotton, cassava, asparagus and vegetable in winter. Autumn and spring are transition periods. In some cases, these stubbles are produced by the farmer (he grows crops besides rearing livestock) but in general he purchases stubbles of farmers who do not have animals or establishes exchanges with them (e.g. manure). These exchanges occur frequently worldwide as Asia(8). In some cases, as said, farmers 
además de ganadero, pero en general éste compra rastrojos a otros agricultores que no tienen ganado o establece intercambios con ellos (p.ej. estiércol). Estos intercambios con frecuencia ocurren en otras partes del mundo como en Asia(8). A veces, como se ha dicho, los ganaderos practican la trastermitancia, llevando los rebaños a los pastos naturales de las montañas andinas desde marzo a junio (los animales pastan después de la temporada de lluvias que normalmente se sitúa entre enero y marzo en la costa peruana). Finalmente, en la mayoría de las explotaciones de los VCC, hay cabras que se ordeñan (oscilando entre el 15 y $30 \%$ del total de las cabras de la granja). El ordeño se inicia algunos días después del parto o después del destete de los cabritos y continúa durante más de cuatro meses.

Para la mejora del sector caprino en la costa central peruana, desde 2001 la Universidad Nacional Agraria La Molina (Lima, Perú) en colaboración con la Universidad de Sevilla (España) ha ejecutado varios proyectos de desarrollo(9). Este trabajo es un resultado de dicha colaboración, cuyo objetivo fue caracterizar los sistemas caprinos de la costa central de Perú basados en el aprovechamiento de rastrojos, y exponer algunas sugerencias para la mejora de los mismos.

\section{MATERIALES Y MÉTODOS}

Área de estudio

El área de estudio es el Valle de Cañete de Perú, situado a unos $150 \mathrm{~km}$ al sur de Lima ( $13^{\circ} 02^{\prime} 21^{\prime \prime}$ $\mathrm{S}, 76^{\circ} 29^{\prime} 21^{\prime \prime} \mathrm{O}$ ). Este valle tiene $6,282 \mathrm{~km}^{2}$ y su altitud oscila entre 0 y $150 \mathrm{msnm}$. El clima es árido, desértico y cálido (BWh)(10). La media de lluvia anual oscila entre 10.3 y $16.3 \mathrm{~mm}$ y la temperatura media anual es de $18 \circ \mathrm{C}(11)$. El censo total de caprinos en el área de estudio fue de 2,373 cabezas, en 176 explotaciones(12). Esta área corresponde a la producción caprina basada en el aprovechamiento de rastrojos de cosecha (Figura 1).
Figura 1. Áreas de producción caprina en Perú

Figure 1. Peruvian goat production areas

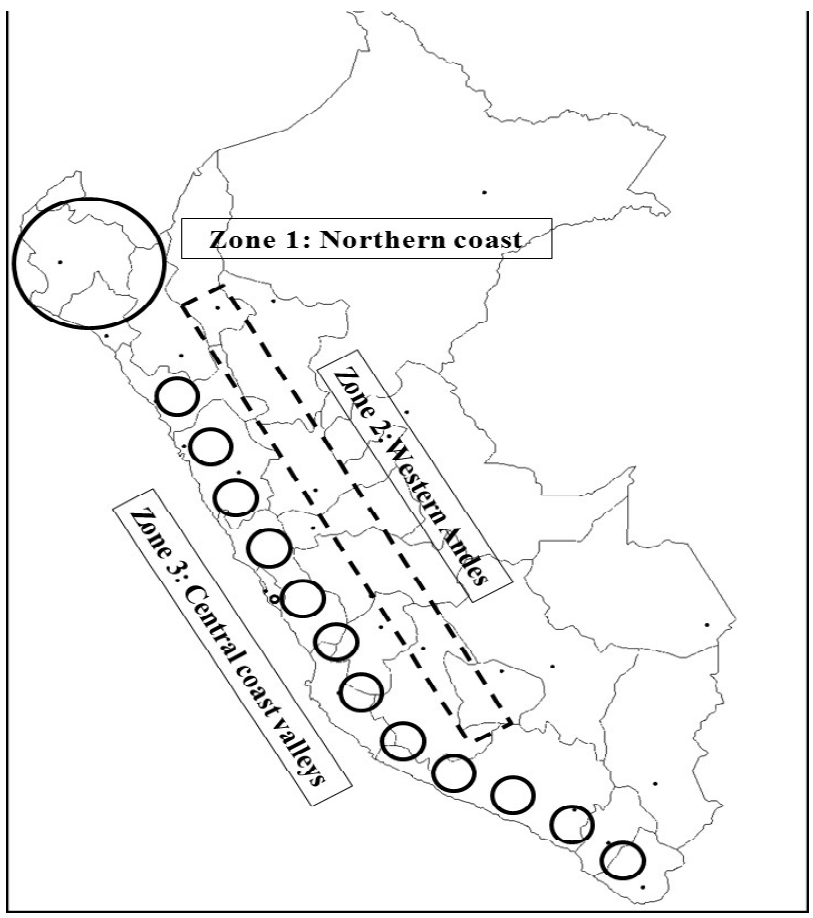

practice a minor form of transhumance, taking the goat herds to rangelands in the Andean mountains. This takes place from March to J une (animals graze after rainfall which usually occurs between J anuary and March). Finally, in many farms of the CCV, there are goats which are milked (ranging from 15 and $30 \%$ of total farmed goats). The milking of goats begins either some days after kidding or after weaning and continues for up to four months.

In order to improve the goat sector in the central coast of Peru, different small-scale development projects have been established since 2001 through the collaboration between the Universidad Nacional Agraria La Molina (Lima, Peru) and the Universidad de Sevilla (Spain) (9). This paper is one result of this collaboration. The aim of this work is to characterize the typical goat production of the central coast of Peru, based on the use of stubble and expose some suggestions in order to improve the system. 
José A. Sarria, et al. / Rev Mex Cienc Pecu 2014;5(4):409-427

Selección de explotaciones y obtención de la información

La información se recopiló en 2008 mediante entrevistas personales semi-estructuradas a 60 ganaderos que tuvieran un mínimo de 10 cabras. El cuestionario se refería a diferentes aspectos del sistema de producción. El Cuadro 1 incluye las siguientes variables: (i) sociología (sexo, edad y nivel de educación del ganadero, principal actividad del ganadero, modo de propiedad de la tierra, formación y consejo técnico recibidos por el ganadero, asociaciones a las que pertenece el ganadero y causas de la no mejora de la explotación); (ii) tamaño de la

\section{MATERIALS AND METHODS}

Study area

The study area is the Valle de Cañete, about $150 \mathrm{~km}$ south of Lima $\left(13^{\circ} 02^{\prime} 21^{\prime \prime} \mathrm{S}, 76^{\circ} 29^{\prime} 21^{\prime \prime}\right.$ W). This valley has $6,282 \mathrm{~km}^{2}$ and altitude ranges from 0 to $150 \mathrm{~m}$ asl. The climate is arid, deser and hot (BWh)(10). The average annual rainfall ranges from 10.3 to $16.3 \mathrm{~mm}$ with an average annual temperature of 18 o $C(11)$. The goat population of the study area was 2,373 head, on 176 farms(12). This area corresponds to the goat production based on stubble grazing (Figure 1).

Cuadro 1. Valores de las variables relativas a la sociología, la dimensión de la granja y el ganado (media y error estándar) para el conjunto del estudio y para cada uno de los grupos

Table 1. Values of sociological, farm dimension and livestock variables (mean and standard error) for the farms of each cluster and for all the farms in the study area

\begin{tabular}{|c|c|c|c|c|c|}
\hline & SA & Cluster 1 & Cluster 2 & Cluster3 & Cluster 4 \\
\hline Farms & 60 & 5 & 13 & 30 & 12 \\
\hline Sex of farmer (male), \% & $53 \pm 7$ & $80 \pm 20$ & $54 \pm 14$ & $57 \pm 9$ & $33 \pm 14$ \\
\hline Farmer's age, yr & $53 \pm 2$ & $51 \pm 3$ & $51 \pm 2$ & $55 \pm 3$ & $51 \pm 4$ \\
\hline \multicolumn{6}{|l|}{ Farmer's education: } \\
\hline No studies, $\%$ & $27 \pm 6$ & $40 \pm 25$ & $23 \pm 12$ & $23 \pm 8$ & $33 \pm 14$ \\
\hline Primary \% * & $43 \pm 7$ & $20 \pm 20 a b$ & $15 \pm 10 b$ & $60 \pm 9 a$ & $42 \pm 15 a b$ \\
\hline Highschool, \% * & $30 \pm 6$ & $40 \pm 25 a b$ & $62 \pm 14 a$ & $17 \pm 7 b$ & $25 \pm 13 b$ \\
\hline Farm area, $m^{2 \star}$ & $1842 \pm 381$ & $5580 \pm 3631 a$ & $2132 \pm 766 b$ & $1151 \pm 238 b$ & $1700 \pm 429) b$ \\
\hline \multicolumn{6}{|l|}{ Land ownership: } \\
\hline Private, $\% * *$ & $77 \pm 6$ & $20 \pm 20 b$ & $69 \pm 13^{a}$ & $83 \pm 7 a$ & $92 \pm 8 a$ \\
\hline Communal, \%* & $7 \pm 3$ & $40 \pm 25 a$ & $8 \pm 8 b$ & $3 \pm 3 b$ & $0 \pm 0 b$ \\
\hline Invaded, \% & $17 \pm 5$ & $40 \pm 25$ & $23 \pm 12$ & $13 \pm 6$ & $8 \pm 8$ \\
\hline GMA, \%*** & $82 \pm 5$ & $40 \pm 25 b$ & $38 \pm 14 b$ & $100 \pm 0 a$ & $100 \pm 0 a$ \\
\hline Number of goats *** & $48 \pm 4$ & $97 \pm 9 a$ & $36 \pm 5 b$ & $32 \pm 2 b$ & $80 \pm 8^{a}$ \\
\hline Number of bovines $* \star \star$ & $8 \pm 1$ & $18 \pm 5 a$ & $16 \pm 2 a$ & $3 \pm 1 b$ & $5 \pm 1 b$ \\
\hline Number of sheep & $7 \pm 1$ & $10 \pm 4$ & $6 \pm 2$ & $7 \pm 1$ & $8 \pm 3$ \\
\hline Farmer has agricultural or trading activity, $\%$ & $18 \pm 5$ & $40 \pm 25$ & $31 \pm 13$ & $10 \pm 6$ & $17 \pm 11$ \\
\hline FBA, \% & $10 \pm 4$ & $0 \pm 0$ & $15 \pm 10$ & $10 \pm 6$ & $8 \pm 8$ \\
\hline CNFI: Unprofitable, \% & $43 \pm 7$ & $60 \pm 25$ & $46 \pm 14$ & $33 \pm 9$ & $58 \pm 15$ \\
\hline Lack of credit, \% & $33 \pm 6$ & $40 \pm 25$ & $31 \pm 13$ & $43 \pm 9$ & $8 \pm 8$ \\
\hline PPF, \% & $23 \pm 6$ & $0 \pm 0$ & $23 \pm 12$ & $23 \pm 8$ & $33 \pm 14$ \\
\hline Farmer's training, \% & $5 \pm 3$ & $0 \pm 0$ & $8 \pm 8$ & $3 \pm 3$ & $8 \pm 8$ \\
\hline Lack of technical advice, \% & $28 \pm 6$ & $40 \pm 25$ & $15 \pm 10$ & $27 \pm 8$ & $42 \pm 15$ \\
\hline
\end{tabular}

$\mathrm{SA}=$ Studied area; $\mathrm{GMA}=$ Goat is main activity; $\mathrm{FBA}=$ Farmers belong to an association; $\mathrm{CNFI}=$ Causes of no farm improvement; $\mathrm{PPF}=$ Poor promising future.

ab Values with different letters on the same row are different ${ }^{*}(P<0.05) ;{ }^{* *}(P<0.01) ;{ }^{* * *}(P<0.001)$. 
explotación; y (iii) características del rebaño (número de caprinos, bovinos y ovinos). El Cuadro 2 incluye las siguientes variables relativas al manejo del rebaño: (i) alimentación (uso de pastos naturales, suministro de alimento en el pesebre y proporción de cultivos forrajeros); (ii) reproducción (origen y manejo de las hembras, época de partos y edad de destete); y (iii) salud animal (vacunaciones, desparasitación y desinfección de las mamas). El uso de los pastos naturales se refiere al traslado del rebaño desde las granjas del estudio hasta las áreas andinas. En verano o en otoño y durante unos tres meses, los rebaños van desde las granjas en dirección a las sierras andinas caminando un máximo de $100 \mathrm{~km}$ (trastermitancia). El Cuadro 3 incluye variables relativas a la producción (lactación) y comercialización: (i) principal producción de la granja; (ii) destino del queso; (iii) época de venta de los cabritos; y (iv) destino del estiércol.

La información obtenida se plasmó en 34 variables ( 7 cuantitativas y 27 categóricascualitativas). De estas últimas, 23 eran binarias (si/no) y 4 tenían tres opciones. Para las
Selection of farms and information collection The information for this study was collected in 2008 through personal interviews with 60 farmers who had at least 10 goats. The survey questionnaire included questions regarding different production system aspects. Table 1 includes the following variables: (i) sociology (sex, age and education level of farmer, farmer's activity, type of land ownership, training and technical advice received by the farmer, associations concerning the farmer and causes of no farm improvement); (ii) farm size; and (iii) livestock characteristics (number of goats, bovine animals and sheep).

Table 2 includes the following variables concerning the herd management: (i) feeding (use of rangelands, feeding in the trough and proportion of fodder crops); (ii) reproduction (origin and management of females, kidding season and kid weaning age); and (iii) animal health (vaccination, worming and udder disinfection). The use of rangelands refers to transfer of the goat herd in the study area from farms to Andean Sierra. For about $3 \mathrm{mo}$ in summer or in autumn, the herds leave the farms in the Andean Sierra

Cuadro 2. Valores de las variables relativas a la alimentación, reproducción y salud de los animales (media y error estándar) para el conjunto del estudio y para cada uno de los grupos (\%)

Table 2. Values of feeding, reproduction and animal health variables (mean and standard error) for the farms of each cluster and for all the farms of the study area (\%)

\begin{tabular}{|c|c|c|c|c|c|}
\hline & SA & Cluster 1 & Cluster 2 & Cluster 3 & Cluster 4 \\
\hline Farms & 60 & 5 & 13 & 30 & 12 \\
\hline Use of rangelands & $10 \pm 4$ & $20 \pm 20$ & $0 \pm 0$ & $7 \pm 5$ & $25 \pm 13$ \\
\hline No food in trough $* * *$ & $65 \pm 6$ & $100 \pm 0 \mathrm{a}$ & $38 \pm 14 b$ & $57 \pm 9 a b$ & $100 \pm 0 \mathrm{a}$ \\
\hline Fodder crops & $8 \pm 4$ & $20 \pm 20$ & $15 \pm 10$ & $7 \pm 5$ & $0 \pm 0$ \\
\hline Separates by sex & $12 \pm 4$ & $0 \pm 0$ & $15 \pm 10$ & $10 \pm 6$ & $17 \pm 11$ \\
\hline Males purchased from the region & $87 \pm 4$ & $60 \pm 25$ & $77 \pm 12$ & $93 \pm 5$ & $92 \pm 8$ \\
\hline Winter and spring are the main kidding season & $58 \pm 6$ & $80 \pm 20$ & $46 \pm 14$ & $57 \pm 9$ & $67 \pm 14$ \\
\hline Kids weaned at $4 \mathrm{mo}$ & $10 \pm 4$ & $20 \pm 20$ & $0 \pm 0$ & $10 \pm 6$ & $17 \pm 11$ \\
\hline Vaccinates animals & $85 \pm 5$ & $60 \pm 25$ & $100 \pm 0$ & $80 \pm 7$ & $92 \pm 8$ \\
\hline Internal worming & $83 \pm 11$ & $100 \pm 0$ & $92 \pm 8$ & $80 \pm 7$ & $83 \pm 11$ \\
\hline External worming & $43 \pm 7$ & $20 \pm 20$ & $62 \pm 14$ & $40 \pm 9$ & $42 \pm 15$ \\
\hline Udders washed and disinfected after milking & $23 \pm 6$ & $60 \pm 25$ & $8 \pm 8$ & $27 \pm 8$ & $17 \pm 11$ \\
\hline
\end{tabular}

$\mathrm{SA}=$ Studied area.

ab Values with different letters on the same row are different ${ }^{*}\left(P<0.05 ;{ }^{* *}\left(P<0.01 ;{ }^{* \star *}(P<0.001)\right.\right.$. 
variables con tres respuestas, se crearon 3 nuevas variables, una por opción. Los valores de todas las variables cualitativas se expresan en forma de porcentajes.

\section{Análisis estadístico}

Se llevó a cabo un análisis multivariante que incluye dos pasos: un análisis de componentes principales (ACP) y un análisis cluster $(A C)(13,14)$. El ACP busca una combinación lineal de las variables que obtenga la máxima varianza de ellas y después identifica una segunda combinación lineal para explicar la varianza restante, dando lugar a nuevas variables ortogonales (sin correlación estadística), llamadas cada una de ellas componente principal (CP) o factor. El propósito del ACP es reducir el número de variables y por tanto la dimensión del problema $(15,16)$. Se pueden utilizar tres tipos de ACP: análisis de correspondencias, escalonamiento óptimo y análisis factorial, dependiendo de si las variables a analizar son respectivamente todas cualitativas, mixtas (cualitativas y cuantitativas) o todas cuantitativas $(13,14)$. En el presente estudio las variables son cualitativas $y$, en menor número, direction, and walk a maximum of $100 \mathrm{~km} \mathrm{(a}$ minor form of transhumance).

Table 3 includes variables concerning production (milking process) and marketing: (i) main farm production; (ii) cheese destination; (iii) kid selling season; and (iv) manure destination. The information obtained from the questionnaire was divided into 34 variables ( 7 quantitative and 27 categorical-qualitative). Of the categorical qualitative variables, 23 were binary (yes/no) and 4 had three answer options. In this last case, a variable for each one of these options has been established. Values of each are the percentages of this option.

\section{Statistical analysis}

A multivariate analysis was conducted which include two steps: the principal component analysis (PCA) and the cluster analysis $(C A)(13,14)$. The PCA looks for a linear combination of variables that extracts maximum variance from them and then identifies a second linear combination to explain the remaining variance, leading to new orthogonal (statistically uncorrelated) variables, each of them called principal component (PC) or factor. The purpose

Cuadro 3. Valores de las variables relativas a producción y marketing (media y error estándar) para el conjunto del estudio y para cada uno de los grupos

Table 3. Values of production and marketing variables (mean and standard error) for the farms of each cluster and for all the farms of the study area

\begin{tabular}{|c|c|c|c|c|c|}
\hline & SA & Cluster 1 & Cluster 2 & Cluster 3 & Cluster 4 \\
\hline Farms & 60 & 5 & 13 & 30 & 12 \\
\hline Farmer tries to milk all goats, $\%$ & $75 \pm 6$ & $60 \pm 25$ & $85 \pm 10$ & $83 \pm 7$ & $50 \pm 15$ \\
\hline Farmer starts milking after weaning, \% & $68 \pm 6$ & $80 \pm 20$ & $69 \pm 13$ & $70 \pm 9$ & $58 \pm 15$ \\
\hline Duration of milking, mo & $3.9 \pm 0.1$ & $3.4 \pm 0.2$ & $3.8 \pm 0.3$ & $4.0 \pm 0.2$ & $4.0 \pm 0.3$ \\
\hline \multicolumn{6}{|l|}{ Main farm production: } \\
\hline Milk, \% & $22 \pm 5$ & $20 \pm 20$ & $23 \pm 12$ & $20 \pm 7$ & $25 \pm 123$ \\
\hline Cheese, \% & $62 \pm 6$ & $60 \pm 25$ & $54 \pm 14$ & $63 \pm 9$ & $67 \pm 14$ \\
\hline Meat, \% & $17 \pm 5$ & $20 \pm 20$ & $23 \pm 12$ & $17 \pm 7$ & $8 \pm 8$ \\
\hline Farmer sells cheese to intermediaries, $\%$ & $28 \pm 6$ & $20 \pm 20$ & $46 \pm 14$ & $30 \pm 9$ & $8 \pm 8$ \\
\hline Farmer sells kids in undefined season, \% & $57 \pm 7$ & $40 \pm 25$ & $62 \pm 14$ & $60 \pm 9$ & $50 \pm 15$ \\
\hline Household consumes some cheese, \% & $80 \pm 5$ & $100 \pm 0$ & $69 \pm 13$ & $77 \pm 8$ & $92 \pm 8$ \\
\hline Farmer sales the manure, $\%$ & $85 \pm 5$ & $80 \pm 20$ & $100 \pm 0$ & $77 \pm 8$ & $92 \pm 8$ \\
\hline
\end{tabular}

$\mathrm{SA}=$ Studied area. 
cuantitativas, se empleó el análisis de escalonamiento óptimo. La varianza de los CPs se ha medido mediante los autovalores. El primer CP se asoció al autovalor de mayor cuantía. Los siguientes CPs se asociaron a los auto valores decrecientes $(13,16)$. Con frecuencia, los autores toman los valores mayores que 1 para seleccionar el número de $\mathrm{CP}(16)$, siendo éste el criterio seguido en este trabajo. Para que una variable cuantitativa sea seleccionada para el análisis multivariante debe tener un coeficiente de variabilidad medio-alto; sin embargo, cuando algunas de ellas están correlacionadas sólo se usan para el análisis aquéllas que se consideran más importantes según el criterio de los expertos $(13,15)$. En cualquier caso, la selección de variables para la caracterización depende del manejo del sistema de producción, de los objetivos de la caracterización y de otros factores, pero sobre todo depende de la información que se pueda obtener de las explotaciones y del medio ambiente en el que éstas se desenvuelven(14). Además, cada autor trata de seleccionar las variables más interesantes, especialmente en el caso de las variables cualitativas(16).

Después de realizar el $A C P$, las granjas se clasificaron mediante un AC. Para llevar a cabo este análisis, en lugar de usar todas las variables, se usaron los CPs obtenidos en la primera parte del análisis multivariante $(13,15,16)$. En cuanto a la elección del número de grupos, la literatura no establece normas fijas. Este número puede ser predefinido por los investigadores (análisis cluster de k-medias) o indefinido (análisis cluster jerárquico)(14). En el presente estudio se utilizó un análisis cluster de k-medias. considerando que la elección del número de grupos debe basarse en la experiencia y objetividad de los investigadores $(13,16)$. Finalmente, se realizó un ANOVA para diferenciar el efecto de los grupos obtenidos en cada una de las variables originales, confirmando de este modo el análisis multivariante(14). Para todos los análisis estadísticos se usó el programa SPSS v. 14(17). of PCA is to reduce the number of variables and thus the dimension of the problem $(15,16)$. Three kinds of PCA can be applied: correspondence analysis, optimal scaling analysis and factorial analysis, depending if the variables for the analysis are all qualitative, mixed (qualitative and quantitative) or all quantitative respectively $(13,14)$. In the present work there were both qualitative and, although to a lesser number, quantitative variables, therefore an Optimal Scaling Analysis was used. The PCs variability was measured by associated eigenvalues. The first PC was associated to the higher eigenvalue. The next PCs were associated to decreasing eigenvalues $(13,16)$. Very often, authors take values higher than 1 to select the number of PC(16) and this criterion was used in the present study. To be selected for the multivariate analysis, the quantitative variables should have a medium-high coefficient of variability; however, when some of them are statistically correlated only those considered more important according the expert criteria should be used in the analysis $(13,15)$. Anyway, the variable selection for characterization depends of production system management and objectives, as other factors, but depends over all of information characteristics that can be found in farms and in the farm environment(14). Moreover, each author tries to select the more interesting variables(16), especially in the case of qualitative variables.

After the PCA, farms were classified through a CA. To perform this analysis the PC obtained in the first part of multivariate analysis were used instead of all the variables $(13,15,16)$. Concerning the choice of the number of clusters, the literature does not provide fixed rules. This number can be predefined by the scientist ( $k$ means cluster analysis) or undefined (hierarchical cluster analysis)(14). In the present work a k-means cluster analysis was performed to proceed with the farm grouping. This decision is according to different authors $(13,16)$ which stated that the choice of the cluster number should be based on the experience and objectivity of the researcher. Finally, as 


\section{RESULTADOS}

Análisis de escalonamiento óptimo

A partir del análisis de escalonamiento óptimo, se obtuvieron dos $\mathrm{CP}$, los valores propios son 1.409 para el primer CP y 1.385 para el segundo. Las proporciones relativas de la varianza fueron 35.2 y $34.6 \%$ respectivamente, de modo que entre los dos explican el $69.9 \%$ de la varianza total. El primer $\mathrm{CP}$, que se ha llamado 'especialización en la producción caprina', incluye las variables número de bovinos e importancia del caprino (los valores más bajos indican una mayor importancia de la producción caprina y un menor número de bovinos). El Segundo CP, se ha llamado 'intensificación y número de caprinos', incluye las variables número de caprinos y suministro de alimento en el comedero (los valores más bajos indican un mayor suministro de alimentos y un bajo número de caprinos). Los autovectores (pesos) para cada una de las cuatro variables que integran los CPs, en todos los casos con un nivel de significación $\mathrm{P}<0.001$, son los siguientes (el primer y segundo valor muestran respectivamente los pesos para el primer y segundo (C): número de bovinos $(0.808,-0.271)$; importancia de los caprinos (0.800, -0.186); número de caprinos (0.298, $0.770)$; y suministro de alimento en el pesebre $(-0.166,-0.827)$.

Análisis Cluster y clasificación de las explotaciones

Como resultado del análisis cluster, se obtuvieron cuatro grupos con los centroides perfectamente distanciados, de modo que se presentan características comunes entre las granjas del mismo grupo. La Figura 2 muestra la distribución de las granjas en los distintos grupos según los dos CPs. Los Cuadros 1 a 3 muestran los estadísticos descriptivos (media y error estándar) de las variables correspondientes al conjunto de las explotaciones del estudio (primera columna) y a cada uno de los grupos (siguientes columnas). Sólo 7 de las 34 variables analizadas presentan diferencias significativas entre grupos: confirmation analysis, the differentiating effect of the clusters on the original variables was observed and an ANOVA between clusters was performed(14). SPSS v.14 software(17) was used for the statistical analysis in the whole paper.

\section{RESULTS}

Optimal scaling analysis

Results of the Multiple Optimal Scaling Analysis yielded two PC. Eigenvalues are 1.409 for the first PC and 1.385 for the second. The relative proportions of variance were 35.2 and $34.6 \%$, respectively, and explained $69.9 \%$ of the total original variance. The first PC named 'goat production specialization' includes the variables number of bovines and importance of goats (lower values indicate greater importance of

Figura 2. Distribución de las granjas según los dos componentes obtenidos en el análisis multivariante

Figure 2. Distribution of farms according to the two components obtained from multivariate analysis

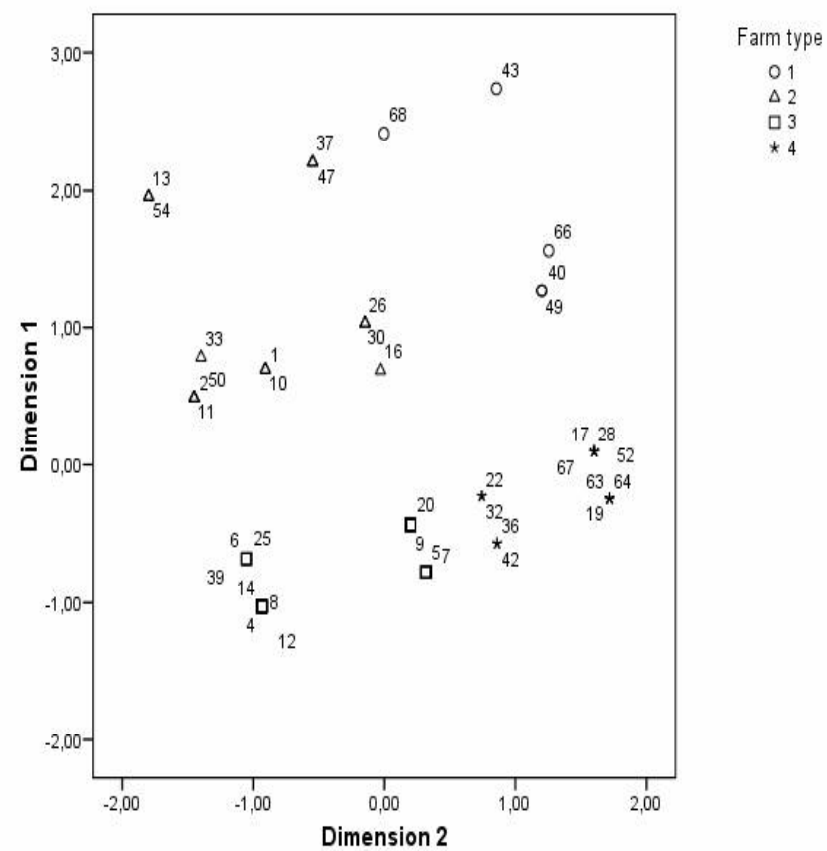

First component: lower values indicate higher importance of goat production and lower number of bovine animals. Second component: lower values indicate greater proportion of farms with feed supply and lower number of goats 
nivel educativo del ganadero, superficie de la explotación, modo de propiedad, importancia del caprino, número de caprinos, número de bovinos y suministro de alimento en el pesebre.

Para resumir, los grupos se pueden describir del siguiente modo:

Grupo 1: los bovinos y los caprinos tienen similar importancia en la explotación. Este grupo incluye sólo cinco granjas (es el grupo más pequeño), que son las más grandes del estudio en cuanto a superficie y a número de cabras. La proporción de granjas que son de propiedad privada es menor que en los otros grupos. Las granjas no están especializadas en el caprino y no se suministra alimento en el pesebre.

Grupo 2: los bovinos son más importantes que los caprinos. Este grupo incluye 13 granjas de tamaño medio y es el que tiene la mayor proporción de ganaderos que suministran alimento en el pesebre.

Grupo 3: los ganaderos están especializados en la producción caprina pero tienen un bajo número de animales (18 caprinos). Es el grupo más representativo del estudio (30 granjas de pequeño tamaño). Una elevada proporción de ganaderos suministran alimento en el pesebre (43\%) pero esta proporción es menor que en el Grupo 2 (62\%).

Grupo 4: los ganaderos están especializados en la producción caprina y tienen un relativo elevado número de animales (60 caprinos). Este grupo incluye 12 granjas de tamaño medio en cuanto a superficie y los ganaderos no suministran alimento en el pesebre en ningún caso.

\section{DISCUSIÓN}

Como se ha comentado en los resultados, sólo siete variables presentan diferencias significativas entre los valores de los distintos grupos. Ello indica que existe una relativa homogeneidad en los sistemas de producción caprina de la goat production and lower number of bovine animals). The second PC 'Intensification and number of goats' includes the variables number of goats and feed supply in the trough (lower values indicate more feed supply and lower number of goats). The eigenvectors (weights) for each of the four variables according to the two PCs, in all cases with a significance level $\mathrm{P}<0.001$, are the following (showing the first and the second values respectively the weights for the first and the second PC): number of bovines (0.808, -0.271$)$; importance of goats $(0.800$, $0.186)$; number of goats $(0.298,0.770)$; and feed supply in the trough $(-0.166,-0.827)$.

Cluster analysis and farm classification

As a result of the cluster analysis, four clusters with perfectly distanced centroids are obtained which yield interesting and common features among farms from the same cluster. Figure 2 shows the distribution of farms according to the two PCs.

Tables 1 to 3 show descriptive statistics of variables (mean and standard error) referring to the database as a whole (first column) and to each cluster retained (following columns). Only 7 of the 34 variables analyzed showed statistical differences between the systems: farmer's education level, farm surface area, type of land ownership, importance of goats, number of goats, number of bovines and feed supply in the trough.

To summarize, the clusters could be described in the following way:

Cluster 1: Similar importance in bovine and caprine production. It includes only five farms (the smallest cluster) which are relatively large (surface area and number of goats). The proportion of farms with private ownership is less than in other clusters. Farms are not specialized in goat production. No farms supply feed in the trough.

Cluster 2: Bovine production is more important than goat production. It includes 13 farms of 
costa central peruana (es decir las granjas son bastante similares entre sí) en comparación con los sistemas de la zona de Piura (Perú) donde se encuentran muchos tipos de sistemas, desde los extensivos con cabras de aptitud cárnica hasta los que utilizan cabras orientadas a la producción de leche(1).

La superficie de las granjas estudiadas es siempre pequeña, con menos de 0.5 ha; únicamente las granjas del Grupo 1 tienen más de 0.5 ha, existiendo diferencias significativas en relación con los otros grupos. Sin embargo, en el norte de Perú (Piura), las granjas son en general extensivas con superficies que oscilan entre 5 y 100 ha(1).

En todos los grupos una importante proporción de los ganaderos considera que su principal actividad es la producción caprina, siendo esta proporción del 100 \% para los Grupos 3 y 4. Sin embargo, los grupos con mayor número de cabras, con diferencias significativas, son el 1 y el 4 (97 y 80 caprinos respectivamente). La presencia de ovinos es escasa (sólo siete animales de media), lo que es similar en todos los grupos. En cambio, el número de bovinos es relativamente importante, especialmente en los Grupos 1 y 2 . Aunque las granjas de estos dos grupos tienen mayor superficie y número de bovinos que los Grupos 3 y 4, no se ha encontrado correlación estadística entre el número de bovinos y la superficie de la granja. No obstante, como resultado de un ANOVA se han encontrado diferencias significativas $(P<0.001)$ en la variable número de bovinos respecto a la variable principal actividad del ganadero. De modo que, en las granjas en las que la actividad caprina del ganadero es importante, la media y error estándar del número de bovinos son $6( \pm 1)$ mientras que cuando la actividad caprina tiene menos importancia, los valores son $14( \pm 3)$.

Considerando la actividad agraria y comercial del ganadero, como complemento a la actividad ganadera, sólo en el $18 \%$ de los casos el criador practica estas actividades, perteneciendo medium size (surface area and number of goats). This cluster has the highest proportion of farms which supply feed in the trough.

Cluster 3: Goat production specialized with a low number of animals (18 goats). It is the most representative cluster of the study area. It includes 30 small farms (surface area). A large proportion of farms supply feed in the trough (43\%) but less than farms of Cluster 2 (62\%).

Cluster 4: Goat production specialized with a relatively high number of animals (60 goats). It includes 12 farms of medium size (surface area). No farms supply feed in the trough.

\section{DISCUSSION}

As noted in the results, only seven variables present significant differences between values of the different clusters. That means a relative homogeneity in goat production systems of the central coast valleys (farms are quite similar to each other) compared to Piura's Peruvian area goat systems where there were many types of farm, from the extensive farms with meat purpose goats to the specialized dairy farms(1).

The surface area of the farms studied is always small, less than 0.5 ha; only farms of the Cluster 1 have above 0.5 ha, which has a significant difference in relation to values of other clusters. However, in northern Peru (Piura), farms are in general extensive with surface areas ranging from 5 to $100 \mathrm{ha}(1)$.

In all clusters a large proportion of farmers consider that goats are their main activity, this proportion being $100 \%$ for Clusters 3 and 4 . However, clusters with a higher number of goats with a significant difference are 1 and 4 (97 and 80 female goats, respectively). The presence of sheep is scarce (only seven animals on average), and is similar in all clusters. However, the number of bovine animals is relatively important, especially in Clusters 1 and 2 . Although farms of these two clusters have higher 
sobre todo a los Grupos 1 y 2, en los que hay menos ganaderos expertos en la producción caprina, y la proporción que practica actividades no ganaderas asciende al 40 y $31 \%$ respectivamente.

En relación al número de caprinos, los rebaños de este estudio son más bien pequeños, oscilando entre 32 (Grupo 3) y 97 (Grupo 1), mientras que en la zona de Piura (al norte de Perú) los rebaños tienen tamaños más variables que oscilan entre 8 y 118 animales(1). Se sabe que las granjas necesitan tener un tamaño mínimo para que el trabajo realizado en ellas sea eficiente. En cada país o región existen condiciones diferentes, pero evidentemente el tamaño en el área de estudio es excesivamente pequeño (48 caprinos de media), incluso teniendo en cuenta que se explotan también otras especies animales.

En relación con las características del ganadero, casi la mitad de los involucrados fueron mujeres (47 \%), predominando dicho género en el Grupo 4 (67 \%) mientras que los hombres predominan en el Grupo 1 (80 \%). La elevada proporción de mujeres se debe a que en los países emergentes, incluido el Perú, es habitual la separación del mercado de trabajo, de modo que mientras los hombres a menudo trabajan tanto dentro como fuera de la granja, las mujeres tienen pocas oportunidades de realizar trabajo fuera de su residencia(18).

El Grupo 1 es el único en el que la propiedad privada de la tierra tiene significativamente menos importancia respecto a los otros grupos (20\% de las granjas) mientras que tanto la propiedad comunal como la propiedad invadida se dan cada una de ellas en el $40 \%$ de los casos. En los otros grupos, la propiedad privada de la tierra predomina y la que tiene menos importancia es la propiedad comunal (8, 3 y $0 \%$ en los Grupos 2, 3 y 4 respectivamente).

La proporción de ganaderos de este estudio que tienen estudios primarios es relativamente mayor que la media de Perú (43 vs $23 \%$, respectivamente) mientras que la proporción area and number of bovine animals than farms of Clusters 3 and 4, no correlations were found between the number of bovines and the farm area. However, as result an ANOVA, significative differences $(P<0.001)$ were found in the variable number of bovines according the two options of the variable farmer's main activity'. So that, in farms with high importance of the farmer's caprine activity, the mean and standard error of bovine animal number are 6 $( \pm 1)$ while in farms with less importance of caprine activity these values are $14( \pm 3)$.

Regarding the agricultural and commercial activities in addition to livestock farming, only $18 \%$ of the farmers in this study practices any of these activities, and belong overall to Clusters 1 and 2, in which the expert farmers proportion in goat farming is less and the nonlivestock activities proportion increases until 40 and $31 \%$ respectively.

Concerning the number of goats, herds of this study are quite small, ranging between 32 (Cluster 3) and 97 (Cluster 1) animals, while in the caprine area of Piura (northern Peru), herds have a more variable size ranging from 8 to 118 animals(1). It is known that farms need to be a minimum size in order for the workforce to be efficient. In each country or region conditions are different, but evidently the farm size in the study area (48 goats on average) is low, even when other animal species are raised on the farm.

In relation to the farmer characteristics, almost half of the farmers of this study are women (47\%). They are predominant in Cluster 4 (67\%), while men predominate in Cluster 1 (80\%). This relatively high proportion of women farmers is the consequence of the typical segregated job market of developing countries, including Peru, where women have less opportunity to work in non-agricultural tasks while their husbands work often also outside the farm(18).

Cluster 1 is the only where private land ownership is of significantly less importance ( $20 \%$ of farms), where $40 \%$ of the farms 
que tienen estudios secundarios es similar (30 vs $38 \%$, respectivamente)(19). Estas proporciones son mejores que las encontradas en trabajos relativos en otros países de Latino América, como al oeste de la Pampa Argentina(5), donde sólo el $13 \%$ de los ganaderos caprinos tenían estudios primarios y el $2 \%$ tenían estudios secundarios. El nivel de educación de los ganaderos es una variable significativa en este estudio. En el Grupo 3 predominan los ganaderos con estudios primarios (62\%) mientras que en el Grupo 2 hay más ganaderos con estudios secundarios (60 \%). Pero lo más destacado es que los ganaderos más especializados en la producción caprina tienden a tener estudios primarios (Grupos 3 y 4), mientras que los ganaderos menos especializados (Grupos 1 y 2 ) tienden a tener estudios secundarios. Sin embargo, a pesar de que los ganaderos del área de estudio cuentan con un nivel educativo aceptable, tienen un bajo interés en la formación profesional, ya que sólo un $5 \%$ han realizado algún curso en este sentido. La edad de los ganaderos es elevada (53 años). La mayoría de las granjas están dirigidas por ganaderos de edad avanzada debido a que los más jóvenes prefieren emigrar a grandes ciudades cercanas en busca de oportunidades de trabajo(3).

Respecto al manejo de la explotación, en general, los ganaderos de este estudio usan poca tecnología, siendo ello similar a lo que ocurre en la mayoría de las granjas de rumiantes de Perú(20). El manejo de la reproducción es deficiente; sólo en el $12 \%$ de los casos los machos se separan de las hembras, y por ello los periodos de parto se distribuyen a lo largo de todo el año. El $75 \%$ de los ganaderos intenta ordeñar todas las cabras después del parto, aunque sólo entre el 15 y el $30 \%$ de los casos éstas tienen suficiente leche para que el ordeño valga la pena. El proceso de ordeño se inicia a los pocos días del parto o tras el destete en el 32 y el $68 \%$ de los casos respectivamente, siendo el período de ordeño medio declarado de 3.9 meses. En cualquier caso, la mejora genética de los animales es una tarea calificada are communal property and $40 \%$ are on invaded land. In other clusters, private land ownership predominates and the communal property is the least important (8, 3 and $0 \%$ in Clusters 2, 3 and 4 respectively).

The proportion of farmers with primary education is relatively high in comparison to the Peruvian average (43 vs $23 \%$, respectively) whereas the proportion of secondary education is similar ( 30 vs $38 \%$, respectively) (19). These proportions are better than those found in other countries of Latin America such as the West Pampa (Argentina)(5), where only $13 \%$ of goat farmers had primary education and a mere $2 \%$ had secondary education. 'Farmer's education level' is a significant variable in this study. In Cluster 3 farmers with primary education (62\%) are predominant while in Cluster 2 there are more farmers with secondary education (60\%). But the more outstanding is that farmers more specialized in goat production tend to have primary education (Clusters 3 and 4) while farmers less specialized (Clusters 1 and 2) tend to have secondary studies. However, despite the acceptable level of education, farmers of the study area have less interest in professional training; only $5 \%$ have a family member who has completed a training course. The average age for farmers is high (53 yr). The majority of farms are managed by older farmers because young people in general prefer to migrate to the big cities in search of better working opportunities(3).

In relation to the farm management, in general, the farms studied use less technology, this being similar in all Peruvian ruminant farms(20). Reproduction management in farms studied is deficient; in only $12 \%$ of cases are males separated from female goats and consequently the kidding periods are distributed throughout the year. The $75 \%$ of studied farmers try to milk all goats that have kidded, although as said, in only between 15 and $30 \%$ of cases there are enough milk to compensate milking. The milking process begins after parturition or 
como importante para los ganaderos, especialmente en los Grupos 3 y 4 en los que la producción caprina es su principal actividad.

En cuanto a la higiene y sanidad de los rebaños, el 85 y el $83 \%$ de los ganaderos respectivamente, realizan vacunaciones y desparasitaciones internas. Los ganaderos muestran poco interés en las desparasitaciones externas, sólo el $43 \%$ las realizan, aunque en el Grupo 2 la proporción alcanza el $62 \%$. La higiene en el proceso de ordeño es también deficiente, ya que sólo el $23 \%$ de los ganaderos lavan y desinfectan las ubres después del ordeño.

En todas las granjas de este estudio, la alimentación de las cabras se basa en el uso de los rastrojos. Estos residuos fibrosos de cultivos son de empleo frecuente en la alimentación de los rumiantes en los países asiáticos en vías de desarrollo(8). En algunos rebaños de ovejas y cabras de elevada producción de Irán, el uso de rastrojos va acompañado de la aplicación de nuevas técnicas de reproducción y nutrición(21). En España, como en la cuenca mediterránea en general, los rastrojos de los cultivos (sobre todo de cereales, pero también de girasol y de leguminosas anuales) son importantes para la alimentación de los rumiantes, principalmente de las ovejas; sin embargo en las últimas décadas ha aumentado la estabulación de los animales y el abandono de los recursos pastables(22). En cambio, en los sistemas de aptitud cárnica del norte de Perú(1) o de otras zonas de Latino América como en el norte de México(7) las cabras no pastan en los rastrojos sino en pastos naturales. No obstante, en el $10 \%$ de los casos de este estudio, las cabras pastan también en los pastos naturales además de aprovechar los rastrojos. Esto ocurre sobre todo en los Grupos 1 y 4 ( 20 y $25 \%$ respectivamente) mientras que en el Grupo 3 los ganaderos no usan los pastos naturales y en el Grupo 4 sólo lo hacen el $7 \%$. Pocos ganaderos cultivan forrajes (8\%), siendo las proporciones más elevadas las de los Grupos 1 after weaning in 32 or $68 \%$ of cases respectively, and the milking period is $3.9 \mathrm{mo}$ on average. Anyway, the improvement of the animal genetic characteristics is another important challenge for the farmers, especially in Clusters 3 and 4 where goat production is the farmer's main activity.

Concerning hygiene and health, 85 and $83 \%$ of farmers respectively vaccinate and do internal worming. Farmers have less interest in external worming; practiced by only $43 \%$ of farmers although in Cluster 2 this proportion rises to $62 \%$. The hygiene is also deficient in the milking process; only $23 \%$ of farmers wash and disinfect udders after milking.

In all farms of the study area, goat feeding is based on stubble grazing. That is according to a general issue: the fibrous crop residues form the basis of feeding systems for ruminants throughout the developing Asian countries(8). In some very productive flocks of sheep and goats of Iran, the use of crop residues is accompanied by the application the new techniques of breeding and nutrition(21). In Spain, like the Mediterranean basin in general, the agricultural residues of arable farming (mainly stubbles of cereal but also of other plants as annual legumes and sunflower) are an important feed source for the ruminants, specially sheep, however in the last decades a growth in indoor feeding practices and an abandonment of land based resources has taken place(22). Instead, in meat goat systems in northern Peru(1) or in other Latin American zones such as the north of Mexico(7) goats do not graze on crop stubbles but on rangelands. However, in $10 \%$ of cases of this study, goats graze, besides on stubbles, on rangelands. This occurs overall in Clusters 1 and 4 (20 and $25 \%$, respectively) while in Cluster 3 no farmers use rangelands and in Cluster 4 only $7 \%$. Few farmers have fodder crops ( $8 \%$ ), Clusters 1 and 2 having the highest proportions with 20 and $15 \%$, respectively. This situation is similar in other Latin American areas such as the Córdoba province of Argentina(2) or in many 
y 2 con 20 y $15 \%$ respectivamente. Esta situación es similar en otras zonas de Latino América como en la provincia argentina de Córdoba(2) o en muchas zonas de Asia(8). El $65 \%$ de los ganaderos del estudio no suministran alimentos en el comedero, siendo esta proporción del $100 \%$ en los Grupos 1 y 4. Los ganaderos de estos grupos son los más extensivos y una buena proporción de ellos practican la trastermitancia. "Si se tiene en cuenta que las granjas de los Grupos 1 y 4 son en general la menos y la más especializada respectivamente en la producción de leche de cabra, no se pueden sacar conclusiones sobre la relación de dicha especialización con el manejo de la alimentación. Los alimentos usados para las cabras de este estudio es similar a los usados en general en Perú por vacas lecheras: grano de maíz y residuos de cosechas (maíz, espárragos, algodón, mandioca) y subproductos de la industrias agrarias como semilla de algodón o melazas(18).

Considerando el manejo de la explotación en sentido amplio, se puede decir que la producción caprina en el área de estudio tiene muchas cosas en común con la del norte de Perú(1), Argentina(2) o Venezuela(6). En general, todas estas zonas son semiáridas o áridas y se encuentran problemas tecnológicos en el manejo reproductivo, la mejora genética de los rebaños, el asesoramiento técnico y la disponibilidad de crédito para financiar las inversiones. En este sentido, los ganaderos consideran que los dos principales obstáculos en la producción caprina son la falta de rentabilidad de la producción caprina (43\% de los casos) y la dificultad en obtener crédito (33\%), lo cual ha sido también comentado en otro estudio realizado en el área costera media del Perú(3).

El principal producto obtenido de las cabras por los ganaderos de este estudio es el queso fresco ( $62 \%$ de los ganaderos), mientras que la leche y la carne es el principal producto para el 22 y el $17 \%$ de los ganaderos respectivamente. La mayoría de los ganaderos
Asian areas(8). In the study area $65 \%$ of farmers do not supply feed in the trough and this proportion reaches $100 \%$ in Clusters 1 and 4; consequently, these two clusters include the most extensive farmers and a higher proportion of them practice a minor form of transhumance). Taking into account that farms of Cluster 1 and Cluster 4 are, in general, respectively less and more specialized in goat production, no conclusion can be stated about the feeding management of goats in relation to the specialization in milk production. The type of feed used for goats in the study area is similar to the feed used in Peru for dairy cows: maize grain and crop residues (maize, asparagus, cotton, cassava) and industrial byproducts as cottonseed or molasses(18).

Considering the farm management in broad, it can be stated that goat production in the study area have many aspects in common with goat production in northern Peru(1), Argentina(2) or Venezuela(6). In general, all these areas are semiarid or arid and technological problems can be found in reproductive herd management, genetic characteristics of animals, technical advice and availability of credit to finance investments. In this sense, farmers consider that the two main factors which prevent this improvement are the unprofitability of goat production ( $43 \%$ cases) and the difficulty to obtain credit (33\%), which has also been discussed in another study in the central coast of Peru(3).

The main farm product obtained from goats is the fresh cheese (62\% farmers), while the milk and the meat are the main products for 22 and $17 \%$ farmers, respectively. Cheese is sold through intermediaries (28\% farmers) or directly at market (72 \% farmers). However, in $80 \%$ of cases, the farm households consume part of the cheese; 100 and $92 \%$ in Clusters 1 and 4, respectively. Concerning kid production in the study area, in general they are weaned and sold at 2 to 3 mo old. The live weight of kids sold does not appear in the tables of results because only about 
vende el queso directamente en el mercado (72 \%) mientras que el $28 \%$ lo vende a través de intermediarios. No obstante, en el $80 \%$ de los casos, una parte del queso se consume en el hogar del ganadero, siendo esta proporción del 100 y $92 \%$ respectivamente en los Grupos 1 y 4 . Respecto a la producción de cabritos, los ganaderos del estudio en general los destetan y los venden entre los 2 y 3 meses de edad. El peso vivo de los cabritos vendidos no aparece en los cuadros porque sólo menos de la mitad de los ganaderos han proporcionado esta información (los pesos oscilan entre los 15 y $25 \mathrm{~kg}$ ). La edad y peso vivo de los cabritos de este estudio son superiores a los de otras zonas de Latino América, como la situada cerca de Lima(3) o en el norte de la provincia argentina de Córdoba(2); en estas zonas los cabritos se venden con 1.5 meses de edad con un peso vivo de 10 a $12 \mathrm{~kg}$. La tendencia en México es vender los cabritos con $8 \mathrm{~kg}$ de peso vivo(7). En relación al periodo anual de venta de los cabritos, en general ésta se distribuye a lo largo de todo el año (en el $58 \%$ de los casos el período es indefinido). Aunque en este estudio no se han podido obtener datos sobre la proporción de cabritos consumidos en el hogar del ganadero, en general en Perú existe un bajo autoconsumo de productos animales (leche y carne)(18).

\section{PROPUESTAS DE MEJ ORA}

En el corto plazo, se identifican aspectos relevantes que pueden ser mejorados como son los relativos al manejo del ganado. En cuanto al manejo de la reproducción, conviene separar los machos de las hembras, lo cual debe planificarse para conseguir que la producción de leche y cabritos se adapte a la demanda del mercado, consiguiendo mejores precios de venta. En relación al manejo de la alimentación, conviene suministrar más alimento en pesebre, y de ser posible mayor proporción de balanceados. Respecto al manejo higiénico y sanitario, los ganaderos deben controlar las principales enfermedades, especialmente la half of the farmers provided this information in the survey, but in general it is quite varied, ranging from 15 to $25 \mathrm{~kg}$. The age and live weight of kids are higher in the study area than in other Latin American areas, as it is situated nearer Lima(3) or in the north of the province of Córdoba (Argentina)(2); in these areas kids are sold at $1.5 \mathrm{mo}$ with a live weight of 10 to $12 \mathrm{~kg}$; likewise, the current trend in Mexico is to sell kids with a live weight of $8 \mathrm{~kg}(7)$. Concerning the annual period of kid production, in general it is distributed throughout the year and consequently, in $58 \%$ of cases there is an undefined season for kid sales. Even though data on the proportion of kids consumed by the farm household was not provided in this study, in Peru in general the self-consumption of animal products (meat and milk) is scarce(18).

\section{PROPOSALS FOR IMPROVEMENT}

In the short term, some relevant aspects that can be improved have been identified, such as those relating to herd management. Concerning reproduction management, males should be kept separate from the females prior to the mating seasons, which should be planned in order to adapt the milk and kid production period to market demand and thus achieve better selling prices. With regard to animal feeding in general more feed, balanced if possible, should be supplied in the trough. Concerning the hygiene and health management, farmers and technicians should attempt to control the main diseases, especially brucellosis as it is the main obstacle for the sale of unripened cheese. But while improving management on farms, facilities should also be improved, which as stated in the discussion is often limited by the lack of availability of credit to finance investment. To address this situation, more active, consistent and continue actions must be taken by the public authorities (ministries, regional governments) and also by organizations linked to the sector (cooperatives, NGOs, etc.). So far, many plans and projects have not achieved the desired technical and economic 
brucelosis que supone el principal obstáculo para la venta de queso fresco. Al mismo tiempo que se mejora el manejo de la granja, se deben también mejorar las instalaciones, lo cual como se ha dicho en la discusión suele estar limitado por la falta de disponibilidad de crédito para financiar las inversiones. Para abordar esta situación, es preciso que la Administración pública (ministerios, gobiernos regionales, etc.) así como las organizaciones ligadas al sector (Cooperativas, ONG, etc.) asuman posturas más activas, coherentes y sobretodo continúas en el tiempo. Hasta el presente, muchos planes y proyectos no han conseguido el deseado desarrollo técnico y económico de los criadores caprinos rastrojeros debido a su limitación temporal.

En el medio plazo, la mejora más importante de los sistemas estudiados puede ser el incremento del número de cabras, especialmente en los Grupos 2 y 3 . Asimismo es preciso mejorar la genética de los rebaños caprinos en dirección a la producción láctea, aunque dicha mejora debe ser coherente y no solo debe llevarse a cabo por importación de germoplasma sino también por mejora de las razas autóctonas(9). Esto impactará de manera significativa en la productividad y producción en la medida que se implementen también las medidas de corto plazo antes sugeridas. Con el fin de mejorar la comercialización de los productos caprinos, se deben hacer esfuerzos para aumentar el consumo de los mismos en el área de estudio, al mismo tiempo que en las áreas urbanas periféricas. Una buena opción podría ser la venta de queso a los consumidores urbanos, por ejemplo siguiendo el modelo descrito para Marruecos y Túnez(23). En algunos casos, se puede promocionar la fabricación de queso integrando a los ganaderos en la cadena agroalimentaria y en otros casos con financiación privada(24). Pero como comentan estos últimos autores, si se quiere incrementar la producción de leche en una zona, es preciso asegurar que la cantidad incrementada se va a poder vender a un precio adecuado o va a poder ser transformada. De este modo, todas las secciones development of stubble goat breeders due to their limitation in time.

In the medium term, the increase of goat numbers should be among the main goals of farmers to improve their farms, especially in Clusters 2 and 3 . It is also necessary to improve the genetics of goat herds towards milk production, although this improvement should be consistent and should not only be performed by importing germplasm but also by improving indigenous breeds(9). The genetic herd improvement will impact significantly on farm productivity and production. But to achieve this, the short-term measures suggested above should also be implemented. In order to improve the marketing of goat products, efforts should be made to increase their consumption in the study area as well as in urban areas. Selling cheese (at a good price) to urban consumers could be a good option following the model described for Morocco and Tunisia(23). In some cases, cheese factories could be promoted through integration of farmers in the agro food supply chain or through private funds(24). But, according to these last authors, if the amount of milk produced in a zone is to be increased it is necessary to ensure the sales of this increased quantity (transformed or otherwise), at an appropriate price. Thereby, all sections of the agro food supply chain should analyze the evolution of milk production, processing and marketing $(6,24)$. The public administration should collaborate in the sales organization of goat products, especially processed products $(4,24,25)$. On the other hand, goals obtained in the improvement of goat production should be disseminated to the sector and diverse training activities should also be carried out(9). The discontinuity of public policy makers is the main obstacle to implement what in this paper is suggested.

In the long term, a continuous training of farmers should be carried out, trying that these constitute strong associations. Until now these associations have had little success due to the 
de la cadena agroalimentaria deben analizar la evolución de la producción de leche, transformación y comercialización $(6,24)$. La administración pública debe colaborar dentro de lo posible en la organización de la venta de los productos ganaderos, especialmente de los transformados $(4,24,25)$. Por otra parte, los logros conseguidos en la mejora de la producción caprina deben difundirse al sector; al mismo tiempo que se ponen a punto distintas actividades para la mejora técnica de los ganaderos(9). La discontinuidad política de las estructuras públicas es el principal obstáculo para implementar lo sugerido.

A largo plazo, es necesario realizar una capacitación continua de los ganaderos e intentar que estos constituyan asociaciones sólidas, lo cual hasta el presente no se ha alcanzado debido a la idiosincrasia personal existente y a la falta de conocimiento y convicción de las indiscutibles ventajas que se pueden obtener operando en conjunto (menores costos de producción y mayores precios de venta). Por otra parte, dado que los sistemas caprinos estudiados tienen características productivas que los hacen muy cercanos a los sistemas orgánicos, se estima que con poco esfuerzo podría realizarse su conversión de convencionales a orgánicos, adquiriendo así un mayor interés para algunos consumidores, especialmente del área de Lima, que sepan apreciar las cualidades de los productos así obtenidos(26).

\section{CONCLUSIONES E IMPLICACIONES}

En los sistemas de producción caprina de los valles de la costa central peruana, las granjas son de pequeño tamaño (en cuanto a superficie y a rebaño) siendo de similar importancia para la economía familiar, tanto la producción de cabritos como de leche y quesos. La presencia de la mujer es importante en las explotaciones. A pesar de la relativa homogeneidad del manejo de las cabras en las explotaciones, existen diferencias entre ellas en los siguientes aspectos: (i) tipo de producción animal (caprina o bovina), farmer's idiosyncrasy and lack of knowledge of the indisputable advantages to be gained operating together (lower production costs and higher selling prices). On the other hand, since the production characteristics of studied systems are very close to those of organic systems, it can be estimated that converting conventional to organic could be made with little effort. That could be interesting specially to some consumers on the area of Lima, who appreciate the qualities of the organic products(26).

\section{CONCLUSIONS AND IMPLICATIONS}

In the goat production systems of the central coast valleys of Peru, farms have low dimension (surface and herd size) and the milk and cheese production, as well as meat, are a similar importance for the farmer economy. Among farmers, the presence of women is important. Despite the relative homogeneity in the management of goat production systems, it exist differences among farms in some aspects as (i) type of animal production (caprine or bovine), (ii) productive orientation (milk or meat) and iii) supply feed in the trough, which is not related with milk productivity, as expected. In order to assure the continuity of stubble grazing systems, farmers should be improved globally (breeding, feeding, health and marketing). At the same time, farmers should try to increase the size of their holdings and the genetic quality of animals. To improve the marketing, singular products should be offered (better defined and typified, particularly processed products). Direct selling to consumers should be encouraged. On the other hand, the existence and proximity to major markets (Lima) must be taken into account and exploited.

\section{ACKNOWLEDGEMENTS}

Research was funded by the Universidad de Sevilla (Spain) and by the Universidad Nacional 
José A. Sarria, et al. / Rev Mex Cienc Pecu 2014;5(4):409-427

(ii) orientación de la producción (leche o carne) y iii) suministro de alimento en el pesebre, el cual no está relacionado con la productividad lechera de las cabras como sería de esperar. Para asegurar la continuidad de los sistemas caprinos rastrojeros, los ganaderos deben mejorar globalmente los sistemas (reproducción, alimentación, sanidad y mercadeo). Al mismo tiempo, los ganaderos deben tratar de aumentar el tamaño de sus explotaciones y la calidad genética de los animales. Para mejorar la comercialización, deben ofrecerse productos diferenciados (bien definidos y tipificados, especialmente productos transformados). Debe fomentarse una venta más directa o cercana a los consumidores y, por otra parte, hay que tener en cuenta y aprovechar la existencia y cercanía de mayores mercados (Lima).

\section{AGRADECIMIENTOS}

Este trabajo ha sido financiado por la Universidad de Sevilla (España) y por la Universidad Nacional Agraria La Molina (Lima, Perú) como parte de un proyecto de desarrollo. Los autores también agradecen la colaboración de los ganaderos que han participado en el estudio.

\section{LITERATURA CITADA}

1. Perevolotski A. Goat production systems in Piura, Peru: A multidisciplinary analysis. Agricult Sys 1990;32:55-81.

2. Arias $M$, Alonso A. Estudio sobre sistemas caprinos del norte de la provincia de Córdoba, Argentina. Arch Zootec 2002; 51:341-349.

3. Arroyo O. Situación actual y proyecciones de la crianza de caprinos en el Perú. Arch Latinoam Prod Anim 2007; 15(1): 290-293.

4. Pariacote FA. Sustentabilidad económica de sistemas de producción caprinos de baja escala en Venezuela. En Nilton Gómez editor.Tercer Simposio Latinoamericano sobre la crianza en forma sustentable de pequeños rumiantes y camélidos sudamericanos. Abancay, Perú. 2007:1-7.

5. Bedotti D, Gómez A, Sánchez M, García A, Martos J. Aspectos sociológicos de los sistemas de producción caprina
Agraria La Molina (Lima, Peru) as part of a development project. Authors also appreciate the collaboration of the study area farmers.

End of english version

en el oeste pampeano (Argentina). Arch Zootec 2005; 54:599-608.

6. Alejua-Alvarez $\mathrm{H}$, Rodríguez M. Caracterización del circuito caprino en el sector villa Araure (Estado de Lara, Venezuela). Agroalimentaria 2006; 11:111-121.

7. Mellado M. Técnicas para el manejo reproductivo de las cabras en agostadero. Tropical and Subtropical Agroecosystems 2008;9(1):47-63.

8. Devendra C. Perspectiveson animal productionsystems in Asia. Livest Sci 2007;106:1-18.

9. Sarria JA, Castel JM, Delgado-Pertíñez M, Guzmán JL, Celi I. Proyecto US-UNALM: Mejora de la producción del ganado caprino en la costa central del Perú. Primer congreso de investigación en agricultura para el desarrollo. Madrid, España 2011:81-82.

10. Kottek M, Grieser J, Beck C, Rudolf B, Rubel F. World Map of the Köppen-Geiger climate classiûcation updated. Meteorologische Zeitschrift 2006;15(3):259-263.

11. SENAMHI. Estudio agroclimático de la Cuenca del Río Cañete. Convenio de Cooperación SENAMHI-MINAG, Dirección General de Información Agraria, Lima-Perú; 2004.

12. Yacila D. Estudio de las características morfológicas y medidas biométricas de los caprinos criollos en el valle de Cañete [Tesis]. Lima-Perú:UNALM; 2005.

13. Hair JF, Anderson RE, Tatham RL, Black WC. Multivariate data analysis. $5^{\text {th }}$ ed. Prentice Hall International, Upper Saddle River, New Jersey, USA. 1998.

14. Madry W, Mena Y, Roszkowska-Madra B, Gozdowski D, Hryniewski R, Castel JM. An overview of farming system typology methodologies and its use in the study of pasturebased farming system: a review. Span J Agric Res 2013; $11(2): 316-326$.

15. Lesschen JP, Verburg PH, Staal SJ. Statistical methods for analyzing the spatial dimension of chang.es in land use and farming systems. LUCC Report Series No. 7, Wageningen University, the Netherlands. 2005.

16. Castel J M, Madry W, Gozdowski D, Roszkowska-Madra B, Dàbrowski M, LupaW, Mena Y. Family dairy farms in the Podlasie province, Poland: farm typology according to farming system. Span J Agric Res 2010;8:946-961.

17. SPSS. Version 14 software. SPSS Inc., Chicago, Illinois, USA. 2005.

18. Aubron $\mathrm{C}$, Cochet $\mathrm{H}$. Producción lechera en los Andes peruanos: ¿Integración al mercado interno o marginación económica? Anuario Americanista Europeo 2009;6-7:217238.

19. INEI. Censos nacionales: XI de población y VI de vivienda. Instituto Nacional de Estadística e Informática (INEI), Lima, Perú. http://proyectos.inei.gob.pe/Censos2007/. Consultado 20 Feb, 2013. 
MEJORA DE LOS SISTEMAS DE PRODUCCIÓN CAPRINA DE LA COSTA CENTRAL DE PERÚ

20. Almeyda MJ. Plan nacional de innovación tecnológica en bovinos de leche: 2010-2021. INIA, Perú.2009.

21. Kamalzadeh A, Rajabbeygi M, Kiasat A. Livestock production systems and trends in livestock industry in Iran. J Agri Soc Sci 2008; 4: 183-188.

22. Caballero C, Fernández-Santos X. Grazing institutions in Castilla-La Mancha, dynamic or downward trend in the Spanish cereal-sheep system. Agricult Sys 2009;101:69-79.

23. Dubeuf JP, Morand-Fehr P, Rubino R. Situation, changes and future of goat industry around the world. Small Ruminant Res 2004;51:165-173.
24. Paz R, Rodríguez-Sperat R, González VG. Desarrollo territorial y eficiencia sistémica: El caso de la cuenca lechera caprina de Santiago del Estero (Argentina). Territorios 2009; 20-21:111-134.

25. Iñiguez $\mathrm{L}$. The challenges of research and development of small ruminant production in dry areas. Small Ruminant Res 2011;98:12-20.

26. Mena $Y$, Nahed J, Ruiz FA, Sánchez-Muñoz JB, Ruiz-Rojas JL, Castel JM. Evaluating mountain goat dairy systems for conversion to the organic model, using a multicriteria method. Animal 2011;6(4):693-703. 
